\title{
MULTI-FACETED MEDIATION IN THE GUINEA-BISSAU CIVIL WAR
}

\author{
Dr Simon Massey \\ Coventry University (UK)
}

An exchange of gunfire in Bissau city between soldiers loyal to President and mutinous troops supporting the recently dismissed army chief of staff Brigadier Ansumane Mané in the early morning of 7 June 1998 heralded the start of 11 months of civil conflict. 'It was not a huge war', the Economist noted, 'but for the $1 \mathrm{~m}$ people... of Guinea-Bissau, it was devastating...Hundreds of people were killed, the city was destroyed and hundreds of thousands fled into the countryside'. The primary reason for the fighting - irrevocable splits within the government and leading Partido Africano da Independencia da Guiné-Bissau e Cabo Verde (PAIGC) - sat amidst a web of geopolitical machinations and posturing.

Guinea-Bissau became the locus for mediation based, for a large part, on political opportunism. These efforts resulted in a peace operation with ostensible humanitarian motives which, nonetheless, was also marked by strong political impulses. As William Zartman has remarked, 'Africa does not lack mediators'. ${ }^{2}$ In the case of the war in Bissau the gamut of potential intermediaries - regional, African and extra-African - offered assistance. This confusion of good offices led to rival mediation efforts whose polarisation mirrored that on the battlefield.

\section{The background to the conflict}

What led to civil war? By 1998, Guinea-Bissau had moved far away from the original revolutionary vision of political society articulated by cofounder of the PAIGC Aristides Perreira - 'the model which our party builds is one in which participation at the base is guaranteed in all decisions, and at every level, by a democratic organisation and method'. ${ }^{3}$ A disparate population had disengaged from

Economist, 15 May 1999, p.48.

Zartman, I. William, 'Inter-African Negotiations and State Renewal' in John W. Harbeson and Donald Rothchild, African in World Politics: The African State System in Flux (Boulder; Westview, 2000), p.142.

3 Quoted in Davidson, Basil, No Fist is Big Enough to Hide the Sky: The Liberation of Guinea-Bissau and Cape Verde (London and New Jersey: Zed Press, 1981), p.165; see also Cabral, Amilcar, Unity and Struggle (London: Heinemann, 1980); Forrest, Joshua 
a dependent state. Lars Rudebeck's long-term research in the Bissauan village of Kandjadja underscores the sense of frustration that followed a flawed electoral process - 'in spite of democratisation, the gap between society and state is as deep as ever. In a way it is even deeper, as new hopes and expectations have been called forth and quickly betrayed'. 4

Beyond widespread popular unrest with Vieira's authoritarian rule, GuineaBissau's foreign relations add a further key causal factor underlying the civil war. Bissauan foreign policy has concentrated on two interlinked spheres. Firstly, relations with the former colonial power Portugal and the dominant extra-African power in the sub-region, France. As one the world's poorest countries GuineaBissau has relied heavily on external aid. Conditional aid from multilateral donors instigated economic and, latterly, political liberalisation. Both sets of conditions adversely affected Vieira's security of tenure. Stringent fiscal policy deepened deprivation, whilst democratisation seemed to offer, then thwart, opportunity for change.

The second major influence on Bissauan foreign policy has been regional geopolitical dynamics. The troubled relationship with Senegal merges GuineaBissau's extra-continental and regional policies. Since its independence, France has looked to Senegal to protect its interests in the sub-region. Senegal's first President, Leopold Senghor, was pro-West and wary of the PAIGC's socialist ideology. Unlike Sekou Touré in Guinea, Senghor offered no support for the PAIGC during the liberation struggle. Following the PAIGC's victory in 1974 Dakar perceived the border between the two countries as a front line in the Cold War. Mistrust of Bissau's intentions intensified following the outbreak of secessionist violence in the Casamance region of southern Senegal in 1982. There was an affinity between Guinea-Bissau and the Casamance secessionists as a result of the provision of rear bases by sympathetic Casamançais during the war of liberation. Even so, Bissau frequently sought to reassure Dakar that it was not supporting the rebel Mouvement

B., Guinea-Bissau: Power, Conflict and Renewal in a West African State (Boulder: Westview Press, 1992); Galli, Rosemary E., and Jocelyn Jones, Guinea-Bissau: Politics, Economics and Society (London: Frances Pinter 1987); Lopes, Carlos, Guinea-Bissau: From Liberation Struggle to Independent Statehood (London and New Jersey: Zed Books, 1987); Rudebeck, Lars, Guinea-Bissau: A Study of Political Mobilization (Uppsala: Scandinavian Institute of African Studies, 1974).

4 Quoted in Rudebeck, Lars, "'To Seek Happiness": Development in a West African Village in the Era of Democratisation', Review of African Political Economy, 71 (1997), p.84. 
des forces démocratiques de la Casamance (MFDC). ${ }^{5}$ Nonetheless, conservative Senegal saw parallels in Guinea-Bissau's revolutionary origins and the rebellion in Casamance. A strong physical, cultural and historical conjunction exists across the fluid border between the two countries based on Jola ethnicity and a shared history of the Mandinka Kingdom of Gabu. ${ }^{6}$ Jean-Claude Marut conjures the 'spectre of the union of the 3Bs' - a territorial aggregation along the axis of Bissau, Bignona in Casamance and Banjul in Gambia - as a strategic preoccupation in Dakar. ${ }^{7}$

By the early 1990s realpolitik had triumphed. A politico-military accord was framed between Guinea-Bissau and Senegal. This resulted in a reappraisal of where Bissau would look for international patronage. Bissau moved away from Lisbon and closer to Paris with Vieira signalling Guinea-Bissau's entry in to the Franc Zone. Portugal made clear through a series of diplomatic exchanges with Paris and Bissau that it resented this 'poaching' of its influence. Following the disappearance of four French tourists in Casamance in 1995, joint exercises, with French logistical support, were conducted. Although Guinea-Bissau was legally neutral, the Senegalese saw the exercises as a basis for a full-scale offensive against the rebels. An agreed zone of 'hot pursuit' was created giving Senegalese troops access to a strip of Bissauan territory, seven kilometres wide, along the border. The result of this new politico-military rapprochement was the militarisation of the border area and a small-scale refugee crisis as displaced civilians moved into the Casamance and Guinea-Bissau hinterlands. However, Vieira accepted this 'frontière élastique' out of political expediency. ${ }^{8}$ By January 1998 the MFDC was accusing Guinea-Bissau of lending military support to the Senegalese. At the same time, Senegal voiced suspicions that, despite the accord, arms continued to flow from the Guinea-Bissau army to the rebels.

Indeed, since 1990, the MFDC has significantly upgraded its arsenal. Senegal surmised that arms had been obtained from suppliers in the region from Liberian, Gambian and Mauritanian sources, as well as through illegal international smuggling. Sources in Guinea-Bissau had also long been suspect. In late January 1998 a shipment of weapons from the Bissauan army was seized en route to Casamance. Vieira and Prime Minister Carlos Correia were abroad when the scandal broke. The government denied responsibility. The immediate response was the arrest

5 Faye, Ousseynou, 'La crise casamançaise et les relations du Sénégal avec la Gambie et la Guinée-Bissau (1980-1992)', in Momar-Coumba (ed.), Le Sénégal et ses voisins (Dakar-Etoile: Sociétés-Espaces-Temps, 1994), p.202.

6 Marut, Jean-Claude, 'Après avoir perdu l'est, la Guinée-Bissau perd-elle aussi le nord', Lusotopie (1996), p.84.

Ibid., p.84.

Marut, op.cit., p.86. 
of about twenty low ranking soldiers, and the suspension of Armed Forces Commander Mané, from his post for dereliction of duty. ${ }^{9}$

Opposition parties in Bissau made political capital from the affair. Citing structural failure in the chain of command in government and the armed forces, and a breakdown of trust between the two institutions, the National Assembly established a committee to investigate arms trafficking. Although due to report in June 1998, the findings would not be disclosed until 13 April 1999. However, core findings and the tenor of the report became common knowledge in Bissau. Far from endorsing the suspension of Mané, the report blamed high ranking officers in the security forces and implied that the President was aware of the trade, but was unable, or unwilling, to intervene.

Mané's response to suspension was to pre-empt the report and publicly accuse the President of agreeing to arms smuggling. On 6 June 1999 BrigadierGeneral Humbert Gomes replaced him as chief of staff. The day after, and a day before the parliamentary report on arms trafficking was due to be published, about 400 rebel soldiers attacked the Bra barracks complex and the airport in Bissau. A stalemate developed. Vieira blamed opposition parties for fomenting the revolt and predicted imminent defeat for the rebels. Mané proclaimed himself head of an interim military council, the Junta Militar, called for free and transparent elections and counter-claimed that only the risk of heavy casualties prevented him taking the capital. $^{10}$

After three days of fighting a dual intervention took place from neighbouring Senegal and Guinea. Senegal's immediate diplomatic justification, circulated to regional governments, was based on a humanitarian imperative. This rationale was superseded by the explanation that Vieira had invoked mutual defence pacts signed in 1965 with Senegal and 1997 with Senegal, Guinea and Gambia. These 'secret' pacts were of questionable legality. From a Gambian perspective at least, the 1997 pact was seen as a collective security arrangement that precluded intervention in the internal affairs of the signatories. ${ }^{11}$ Senegal and Guinea dispatched 1,300 and 500 troops respectively as part of an intervention that the Senegalese dubbed Opération Gabou. The arrival of foreign forces inflamed the conflict. Within ten days the 300,000 residents of Bissau had nearly all quit the city. Most of Bissau was

9 US Department of State Bureau of Democracy, Human Rights, and Labour, 'GuineaBissau Country Report on Human Rights Practices for 1999', 25 February 2000.

10 IRIN-WA, Weekly Roundup, 52, 12 June 1998; Rudebeck, Lars, 'Guinea-Bissau: Military Fighting Breaks Out', Review of African Political Economy, 77 (1998), pp.484-486.

11 Interview with Dr Sadat Jobe (Minister for External Affairs, Gambia) and Ansumana Ceesay (Director of Political Affairs) Banjul, 27-28 January 2000. 
destroyed. Foreign diplomatic missions were evacuated, and the American embassy demolished. ${ }^{12}$ The conflict expanded. After nearly a month of fighting, international agencies were predicting a humanitarian cataclysm. Fighting intensified in Mansoa, whilst the rebels took the towns of Ingore, Bula, and Bigene on the Casamance border.

Senegalese forces of the Force expéditionnaire sénégalaise en GuinéeBissau (Forex) under the command of Colonel Abdoulaye Fall landed on 10 June. Fall saw his objectives as the consolidation of a bridgehead at the new port, control of approach roads to Bissau and Bra and, finally, the protection of the international airport. ${ }^{13}$ Fiercest fighting was at Bra. On 13 June, following heavy artillery bombardment, the central magazine exploded. Reports that the rebel offensive in Bissau was at the point of collapse proved premature. Two days later, a Dakar daily newspaper described a counter-offensive by rebel forces. Le Soleil in Dakar reported Forex claims that fighters from Atika, the armed wing of the MFDC, had been seen fighting with Junta Militar forces. ${ }^{14}$ Most significantly, it was becoming clear that, the Presidential Guard apart, most Bisauan troops were siding with the rebels. Out of an army whose strength was assessed as 6,800 troops only a few hundred remained loyal. At the start of the conflict Vieira was forced to request external help to replace

IRIN-WA, Update, 230, 16 June 1998.

Le Soleil en ligne $\mathrm{http} / / / \mathrm{www}$.primature.sn/lesoleil/archi4/report.htm 25 May 1999.

Ibid.

Scientia Militaria, South African Journal of Military Studies, Vol 32, $\mathrm{Nr} 1$, 2004. http://scientiamilitaria.journals.ac.za 


\section{MAP OF GUINEA-BISSAU AND REGION}

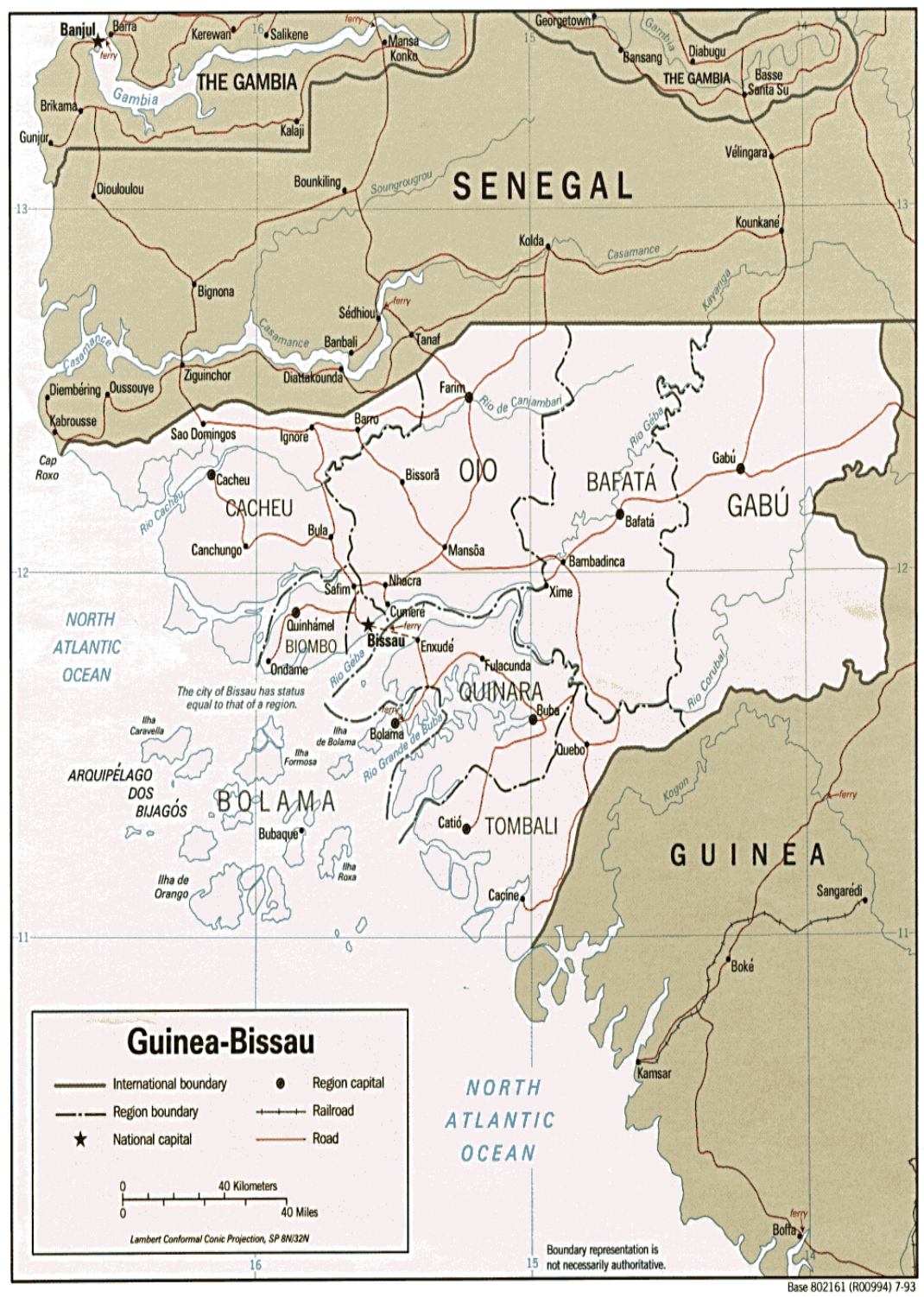

Scientia Militaria, South African Journal of Military Studies, Vol 32, Nr 1, 2004. http://scientiamilitaria.journals.ac.za 
the uniforms of loyalist troops in order to distinguish them on the battlefield. ${ }^{15}$ This problem was short-lived since within weeks most troops fighting on the loyalist side were Senegalese or Guinean. One refugee, quoted by the Missionary News Agency (MISNA), noted that 'we do not see national troops on the government side'. ${ }^{16}$ Moreover, many veteran troops from the liberation era chose to return to arms to fight for the Junta.

The intervention developed into a military disaster for Senegal. At the end of June, Senegalese forces were split, with those reinforcements landed at Buba in the south unable to join the exhausted expeditionary force in Bissau. Moreover, the reinforcements comprised young, trainee conscripts. Almost all the Bissauan population saw the Senegalese troops as 'nothing but an invasion', and 'the biggest impediment to peace negotiations'. ${ }^{17}$ Suffering amongst the civilian population and the numbers of refugees fleeing the Bissau area soon developed into a major humanitarian catastrophe. Most of the capital's 250,000 inhabitants escaped to the east and north of the country. At the same time Amnesty International documented a series of human rights abuses committed by Senegalese, Guinean and loyal Bissauan troops fighting for Vieira. ${ }^{18}$ In Dakar although opposition leaders loudly complained at the manner in which the intervention had been conducted, few politicians objected to the underlying goal of the intervention - to create conditions for a direct assault on MFDC rear bases in Guinea-Bissau with a view to forging a final military solution to the insurrection in Casamance.

Despite apparent popular support for the rebellion, and the marshalling of the vast majority of the armed forces behind Mané, the international community condemned the revolt. The Organisation of African Unity (OAU), the Economic Community of West African States (ECOWAS), the international organisation for lusophone states the Communidade de Paises de Lingua Franca Portuguese (CPLP) and the European Union (EU) each demanded a return to constitutional government.

\section{Multi-faceted mediation}

Condemnation does not solve conflicts. However, at this early stage of hostilities, bilateral negotiation between the combatants was not a realistic option given the mutual distrust engendered by Vieira's 'betrayal' of his former comrade and the existing position on the battlefield with Senegalese and Guinean troops committed to intervention in support of the government and Mané's forces in the

Jeune Afrique, 'Les Sénégalais pris au piège', 1956, 7-13 March 1998.

IRIN-WA, Weekly Roundup, 56, 10 July 1998.

EIU, Country Report: Guinea-Bissau, 3rd Quarter 1998, p.32.

Amnesty International, 'Guinea-Bissau: Human Rights in War and Peace', AI Index AFR 30/07/99. 
ascendancy. The question was who would mediate a conflict with potential for violent contagion and increased regional instability? Involvement in African conflicts by Western powers and the UN had waned following the inconclusive UN Operation in Somalia (UNOSOM) between 1992 and 1995 which many took as a fatal reversal for the putative US-led multinational interventionism of the 'new world order'. The onus for conflict management on the continent had switched to African states and institutions. In terms of mediation the logic of UN Charter Chapter VIII subsidiarity was promoted. The entity closest to a conflict - with the assumption that such an entity would be 'best fit' to address that conflict - would henceforth be preferred as primary mediator. However, which entity is closest or 'best fit' is often contentious.

Chester Crocker, Fen Osler Hampson and Pamela Aall maintain that multiparty mediation has become the norm. ${ }^{19}$ In the Guinea-Bissau civil war several third parties sought, sometimes sequentially, often simultaneously, to mediate the conflict. Crocker et al have isolated various benefits and costs associated with multi-party mediation. The benefits are, however, largely dependent on the various third parties acting in concert towards the common goal of a peaceful settlement of the conflict. If this is the case then a multiplicity of mediators can advance the peace process. Different entities bring different resources at different times, opening new avenues for dialogue thereby generating a mutually supportive environment for mediation. Cooperative mediation might equally multiply potential sources of leverage and facilitate an even distribution of costs and risks. ${ }^{20}$ In the case of Guinea-Bissau there was little unity of purpose amongst the various mediators. The costs of multi-party mediation were more apparent than the benefits. Far from acting with a 'common vision' the mediators acted to divergent and exclusive agendas. For much of the process mediation was conducted in parallel with little shared information or analysis. $^{21}$ The two main mediators, ECOWAS and the CPLP, championed different sides in the conflict. Overt support for Vieira sidelined ECOWAS as the effective lead mediator allowing the CPLP to displace the regional organisation until the latter stages of the conflict.

At the time of the attempted coup the Assembly of Heads of State and Government of the OAU was in session in Ouagadougou, Burkina Faso. As an immediate response the Assembly issued a statement denouncing the mutiny and

19

Crocker, Chester A., Hampson, Fen Osler and Aall, Pamela, 'Is More Better: The Pros and Cons of Multiparty Mediation', in Chester A. Crocker, Fen Osler Hampson and Pamela Aall, Turbulent Peace: The Challenges of Managing International Conflict (Washington DC: US Institute of Peace Press: 2001), p.511.

$20 \quad$ Ibid., pp.508-511.

$21 \quad$ Ibid., pp.506-508. 
urging 'respect for the country's democratically established institutions', whilst calling 'on the people of Guinea-Bissau to rally behind the government of President Vieira' ${ }^{22}$ Could the OAU have taken a lead in mediating the conflict? In June 1993, the OAU had established a Mechanism for Conflict Prevention, Management and Resolution. At the time this groundbreaking initiative was heralded as a juncture in the evolution of African self-pacification. Although the OAU Secretariat and progressive politicians hoped that the adoption of the Mechanism would see the continental body develop the capacity to intervene directly in African conflicts it became clear that lack of funding and political will amongst the majority of member states precluded this ambition. The principles that underpin the Mechanism merely recognise 'the need for [Africa] to take primary ownership of its own problems', and accept that 'the UN together with regional and sub-regional organisations and arrangements should...[frame] new approaches to crisis prevention, management and resolution' ${ }^{23}$ In this regard,

[T]he Mechanism will have as its primary objective, the anticipation and prevention of conflicts. In circumstances where conflicts have occurred, it will be its responsibility to undertake peace-making and peace-building functions in order to facilitate the resolution of these conflicts. ${ }^{24}$

Despite this emphasis on conflict prevention and mediation the OAU's Special Envoy to Bissau, Alexandre Zandemela, played only a peripheral role in mediating the conflict. The Central Organ of the Mechanism met on 13 July and announced that it endorsed ECOWAS as the institution of first resort. In particular it backed the ECOWAS decision to support intervention in Guinea-Bissau by two of its members - Senegal and Guinea. ${ }^{25}$ In calling for the UN Security Council to reinforce this stance, the Central Organ warned 'the international community at large, to desist from according support, in whatever form, to the mutineers' ${ }^{26}$

Richard Jackson has made the point that,

\footnotetext{
22 OAU Conflict Management Division, 'OAU and the Conflict in Guinea-Bissau' http://www.oau-oua.org/document/mechanism/ english/mech10.htm accessed 6 January 2000.

23 Bakwesegha, op.cit.

24 'Declaration of the Assembly of Heads of State and Government on the Establishment Within the OAU of a Mechanism for Conflict Prevention, Management and Resolution', in Resolving Conflicts in Africa: Implementation Options, op.cit., Annex, pp.62-63, para. 15.

25 Panafrican News Agency, 'OAU Calls for Restoration of Legality in Guinea-Bissau', 15 July 1998.

26 OAU Conflict Management Division, 'OAU and the Conflict in Guinea-Bissau' $<\mathrm{http}: / /$ www.oau-oua.org/document/mechanism/english/mech10.htm $>$ accessed 6 January 2000.
} 
[W]hile regional organisations are generally very successful at resolving conflicts... in Africa they show a poor record of success. This is related to a number of inherent weaknesses, and clearly the OAU especially needs major reforms if it is to improve its conflict management role. ${ }^{27}$

In 2002 the OAU was dissolved and the African Union (AU) established. With a view to overcoming the shortcomings of OAU conflict management practice the AU has moved rapidly to construct an effective framework for mediation of conflicts on the continent. In early 2004 the Protocol on the Peace and Security Council (PSC) came into force. Whilst conflict prevention and mediation are stressed, the Constitutive Act of the AU, at least prior to amendment, envisages that this new organ will have wider powers to enforce and police settlements. Whilst the wider aims of the PSC have yet to be realised, there are positive signs - including a series of missions to Africa's conflict areas - that the AU will be more proactive in its approach to conflict management than it predecessor. Yet, Jakkie Cilliers' comment that 'the AU will require a much larger budget than the OAU if it is to contribute to peace and security on the continent' is well made. ${ }^{28}$

In Guinea-Bissau the first efforts at mediation were ad hoc approaches made by disparate African and extra-continental actors. The Ambassadors of Portugal and Angola in Bissau, as well as the Swedish chargé d'affaires were central figures in these initiatives. On 14 June, Libya's Muammar Qadafi sent a high level delegation to Bissau. However, the single most active individual involved in mediation on the ground was the Catholic Bishop of Bissau, Settimio Ferrazzeta. Although less than five per cent of the population belong to the Catholic Church, Ferrazzeta was well respected having lived in the country since 1955 . He met with members of the Junta Militar in the early days of the conflict. Whilst he expressed himself 'hopeful', he felt that the government would find it hard to meet the Junta's terms. ${ }^{29}$ Thomas Prinzen lists several potential resources available to the Catholic Church as an international mediator - moral legitimacy, the ability to advance other's political standing, an international audience, a network of information and contacts, secrecy and neutrality. ${ }^{30}$ Concerning the last he remarks that

27 Jackson, Richard, 'Managing Africa's Violent Conflicts', Peace and Change, 25/2 (2000), p.219.

28 Cilliers, Jakkie, 'Peace, Security and Democracy in Africa? A Summary of Outcomes from the 2002 OAU/AU Summits in Durban' ISS Paper, 60 (2002), p.8.

IRIN-WA, Weekly Roundup, 54, 25 June 1998.

Princen, Thomas, 'Mediation by a Trans-national Organisation: the Case of the Vatican', in Jacob Bercovitch and Jeffrey Z. Rubin, Mediation in International Relations: Multiple Approaches to Conflict Management (London: Macmillan, 1992), pp.167-173. 
$[\mathrm{N}]$ eutrality, in the sense of having no claims on the disputed issues, can be an asset. A mediator is more likely to be acceptable to each side if that mediator has no interests, direct or indirect, in the issues in defeat. Few major powers can make this claim. ${ }^{31}$

There is a distinction between neutrality and impartiality. Unlike strict neutrality, impartiality is based on 'the twin pillars of non-discrimination of person and proportionality of need'. ${ }^{32}$ An impartial mediator might weigh the actions of the combatants, but not discriminate between them as individuals or entities. Strict neutrality is a rare commodity in contemporary mediation. Bishop Ferrazzeta broadly supported the tenets of liberation theology. As the conflict intensified, his public statements betrayed greater understanding for the rebel position. On 6 July he gave a radio interview accusing the Senegalese forces of widespread looting in the capital, and stated that people in Bissau were calling for the withdrawal of the intervention force. ${ }^{33}$ Ferrazzeta died of an illness unrelated to the conflict in January 1999.

The conflict also prompted a concerted mediation effort by near-neighbour Gambia. On 16 June, Gambian President Yahya Jammeh visited Cape Verde, Mauritania, Guinea and Senegal in order to canvass regional opinion on the crisis. At the same time, Gambian Foreign Minister Sadat Jobe met Mané in a fruitless effort to arrange a ceasefire and mediation talks between the two sides in the Gambian capital, Banjul. These twin initiatives heralded a sustained drive by Gambia to find a solution to the crisis. Historical, ethnic and personal links, as well as humanitarian concern, prompted Gambia's diplomatic intervention. However, the prime motivation was an overarching interest in sub-regional security. The outbreak of conflict in Guinea-Bissau was a worrying escalation in violence only a short distance from Gambia's southern border. Banjul recognised a firm link between the secessionist campaign in Casamance and the war in Bissau. Given the proximity, the potential for cross-border contagion, and the possibility of serious refugee flows Gambia clearly had a stake in ensuring a swift resolution to the conflict. Gambian civil servants stress that the main motivation for the country taking a leading role in mediating both crises was the need for a 'comprehensive peace strategy'. ${ }^{34}$ Whilst sub-regional stability was certainly a prime concern in Banjul it should be noted that

$31 \quad$ Ibid., p.68.

32 Slim, Hugo, 'Positioning Humanitarianism in War: Principles of Neutrality, Impartiality and Solidarity', in Stuart Gordon and Francis Toase, Aspects of Peacekeeping (London: Frank Cass, 2001), p.34.

33 IRIN-WA, Update, 246, 8 July 1998.

34 Interview with Essa Khan (Deputy Permanent Secretary in the Ministry of Defence of The Gambia) 24 June 2000. 
both Senegal and Vieira considered Gambia partial. Randa Slim contends that 'the power of the small state as mediator usually resides in its neutrality, and its fair treatment of all parties' basic interests and concerns'. ${ }^{35}$ However, it had not escaped notice in Dakar that Mané had been born in Gambia and had relatives there, although he had long lived in Bissau and was a national hero there. Moreover, President Jammeh shared his Jola ethnicity with the large majority of the Casamançais - his birthplace is on the Gambia-Casamance border - leading to suspicions that he lent his support, moral and practical, to the MFDC rebellion.

On 3 July ECOWAS Ministers of Foreign Affairs and Defence met in Abidjan to discuss the crisis. ${ }^{36}$ Vieira requested that the ECOWAS Monitoring Group (ECOMOG), which was still deployed in a peace-enforcement operation in Sierra Leone, should now intervene in Guinea-Bissau. Claiming that the mutineers showed 'a fierce determination', he maintained that the army mutiny 'threatens peace, security and stability' in the country. ${ }^{37}$ ECOWAS ministers agreed. The meeting endorsed the intervention by Senegal and Guinea. Further, it condemned the mutiny, called for a cessation of hostilities and reaffirmed support for Vieira's government and the democratic process. Whilst accepting a need for negotiation, the ministers accepted that further interventionist measures - including the imposition of sanctions and the use of force by ECOWAS - should not be precluded. This was hubris. A senior Western diplomat was reported as describing military intervention by ECOWAS as 'secondary', adding that ECOMOG could only realistically intervene following a negotiated settlement. This anonymous source also doubted the willingness of Western donors to fund or provide logistical support for any such operation. $^{38}$ Nonetheless, an implementing mechanism was constituted. A Committee of Seven comprising Burkina Faso, Côte d'Ivoire, Gambia, Ghana, Guinea, Nigeria and Senegal with representatives from the Secretariats of the OAU and ECOWAS was established. ${ }^{39}$ The meeting concluded by calling on the Committee of Seven to seek UN approval for the ECOWAS position. At this stage ECOWAS was distinctly more actor than mediator in the conflict.

The endorsement of ECOWAS as the prime organisation to address the conflict by the OAU was recognition of the efforts made by the sub-regional body to manage conflicts in the sub-region. The regional body had been willing and able to

35 Slim, Randa M., 'Small State Mediation in International Relations: The Algerian Mediation of the Iranian Hostage Crisis', in Bercovitch and Rubin, op.cit., p.229.

36 First Joint Meeting of ECOWAS Ministers of Foreign Affairs and Defence on GuineaBissau, Abidjan, 3 July 1998.

Africa Research Bulletin, 1-31 July 1998, p.13189.

IRIN-WA, Weekly Roundup, 55, 3 July 1998.

This became the Committee of Nine when Togo and Cape Verde joined in October. 
deploy peace-enforcement troops in the civil wars in Liberia and Sierra Leone. However, ECOWAS was not an impartial mediator - both these interventions had been, de facto, operations to protect the sitting Head of State. In the Bissau conflict ECOWAS reflexively fell back on this default position to support Vieira. Conflict management strategy within the organisation was seriously hampered by internal rivalries between member states and groupings of member states each with divergent agendas. ECOWAS was established in 1975 as a body designed to ameliorate economic development in the West African sub-region. However, since its inception the organisation has been beset by layered rivalries. A basic schism sets the five anglophone members against the nine francophone members. There are also two lusophone members - Cape Verde and Guinea-Bissau. The francophone axis also sets apart Nigeria, the assumptive regional hegemon as a specific rival. These rivalries have undermined the effectiveness of ECOWAS as both mediator and intervenor. During ECOWAS involvement in the Liberia and Sierra Leone conflicts certain states, notably Cote d'Ivoire and Burkina Faso, acted instinctively against the position adopted by Nigeria. Eric Berman and Katie Sams comment that 'rather than building consensus and strengthening solidarity among ECOWAS member states, these missions have underscored and exacerbated sub-regional tensions'. ${ }^{40}$

The notion of impartiality in mediation is problematic and contingent. It is arguable that the innovative perspective and resources brought to the process by a third party must affect the outcome of the process and hence be partial. In terms of conflict resolution, saliency and the ability to move the process forward and not any perceived impartiality are what count. As noted above, even a supposedly neutral outsider such as the representative of the Catholic Church is liable to adopt a partial position. However, the issue of partiality is most pertinent when the mediating entity is the regional organisation. Ole Elgstrom et al suggest that 'relational partiality is probably an inherent trait in regional insider mediators, as they have asymmetrical historical ties and bonds to the conflicting parties'. ${ }^{41}$ William Nhara, former Coordinator of Conflict Prevention and Research at the OAU's Conflict Management Division, notes that

[D]ue to their cultural affinity and common social and historical configuration, the people of a region normally have more intimate knowledge of the evolution and political sensitivities of the conflict in question...Moreover, their general sense of solidarity, arising from

40 Berman, Eric G. and Sams, Katie E., Peacekeeping in Africa: Capabilities and Culpabilities (Geneva: United Nations Publications, 2000), p.78.

41 Elgstrom, Ole, Bercovitch, Jacob and Skau, Carl, 'Regional Organisations and International Mediation; The Effectiveness of Insider Mediators', Africa Journal on Conflict Resolution, 1 (2003). 
common histories, experiences, geographic contiguity and cultural compatibility, can play a central role in the crucial process of consensusbuilding in times of crisis. ${ }^{42}$

Other commentators are less sanguine. Richard Jackson emphasises the downside of affinity - 'the corollary to the advantages that regional organisations possess...is that they are liable to be too close to the issues and too interested in the outcomes'. 43

The assumption that ECOWAS should take the lead in dealing with the conflict was not universal. ECOWAS support for Vieira as sitting Head of State benefited Senegal and, therefore, Senegal's international patron, France. The outbreak of civil war was an opportunity for Portugal to reassert influence in Guinea-Bissau. Portugal was instrumental in reviving the international lusophone organisation, the CPLP, to mediate the conflict. ${ }^{44}$ The Statutes of the CPLP were signed in Lisbon in July 1996 by the seven international Portuguese-speaking states. Portugal had fought its way out of empire and its post-colonial diplomacy had suffered as a result. The establishment of the CPLP raised hopes that the lusophone countries could move beyond the rancorous denouement of the Portuguese Empire. However, continued suspicion of neo-colonialism and the CPLP's demographic profile had limited the organisation's ambitions. Following the outbreak of war in Bissau the lusofonia offered support to Angola and Portugal in their informal efforts to use their good offices to encourage a negotiated settlement. The organisation took a central role in the mediation effort during the second summit of the CPLP held in Praia, Cape Verde on 13-17 July 1998. A Contact Group, chaired by the Foreign Minister of Cape Verde, was established. The other members were the Foreign Ministers of Mozambique, Portugal and São Tomé and Príncipe, together with senior officials from Brazil and Angola.

A climate of mutual suspicion enveloped the respective diplomatic initiatives of ECOWAS and the CPLP described by one participant as 'sheer rivalry' ${ }^{45}$ FrancoPortuguese competition formed the basis for mistrust. Charles King stresses the

42 Nhara, William, 'The OAU and the Potential Role of Regional and Sub-Regional Organisations', in Jakkie Cilliers and Greg Mills, Peacekeeping in Africa (Braamfontein: The South African Institute of International Affairs, 1995), p.101.

43 Jackson, Richard, 'The Dangers of Regionalising International Conflict Management: The African Experience' Political Science, 52/1 (2000), p.55.

44 Hall, Margaret, 'The Conflict in Guinea-Bissau: The Diplomatic Intervention of the Community of Portuguese-speaking Countries' West African Seminar Series, University College London, 5 February 1999.

45 Interview with William Joof (Permanent Secretary to the Office of the President, Gambia), Banjul, 24 January 2000. 
'tendency of Western powers to gauge the relative success of their involvement in civil wars less in terms of the effect on the warring parties, and more in terms of the way in that such involvement affects the strategic interests (and domestic politics) of those powers themselves'. ${ }^{46}$ Portugal believed that with Nigeria distracted by domestic concerns and the intervention in Sierra Leone, Senegal and Guinea were in a position to promote the francophone position within ECOWAS. The Portuguese line was taken up by the CPLP. Whilst expressing a need for 'an urgent return to constitutional legality', a CPLP spokesman emphasised that 'the Praia meeting must come up with a resolution which will set up a mediation mechanism in GuineaBissau...we have to be realistic'. ${ }^{47}$ ECOWAS Executive Secretary Lansana Kouyate responded to the CPLP statement by alluding to Portugal's 'neo-colonial behaviour. ${ }^{48}$ Whilst briefing the UN Security Council in mid-July, the ECOWAS representative 'appealed to Council members to stop Portugal from 'undermining regional efforts in resolving the conflict as well as to avoid supplying arms to the rebels', given that, 'reports from the Guinea-Bissau indicated that Portugal had already supplied sophisticated satellite communications technology to the rebels' ${ }^{49}$ ECOWAS argued that with Senegalese and Guinean troops on the ground, the focus for any mediation efforts should remain in the region. After five weeks of fighting, a senior Western diplomatic source stated his belief that efforts to find a peaceful solution to the conflict had 'stalled' contending that rivalry between ECOWAS and the CPLP was the cause..$^{50}$ However, the greatest obstacle to a settlement was ECOWAS, or at least the francophone lobby within ECOWAS, to eschew diplomacy in favour of support for a military solution. Portuguese Foreign Minister Jaime Gama complained that 'it is simply not possible to get a ceasefire in GuineaBissau right now because the logic of war has not yet ceded to the logic of peace, ${ }^{51}$

In the event, the first of a series of fragile truces was only two weeks away. A military stalemate obtained in the capital. Losses were increasing on both sides and opposition to the intervention was growing in Dakar. Renewed effort by the CPLP following the Cape Verde summit produced results. The CPLP's success somewhat weakened the prevailing orthodoxy - based on Chapter VIII subsidiarity that the lead actor in conflict management should be the relevant regional organisation on the basis that proximity leads to mutual understanding. Non-

$46 \quad$ King, Charles, 'Ending Civil Wars', Adelphi Paper, 308 (1997), p.81.

47 Pan-African News Agency, 'Guinea-Bissau Crisis Dominates Lusophone Summit', 15 July 1998.

48 EIU, Country Report: Guinea-Bissau, 4th Quarter (1998), p.28.

49 Panafrican News Agency, 'Ecowas Briefs Security Council on Guinea-Bissau Situation', 15 July 1998.

$50 \quad$ IRIN-WA, Weekly Roundup, 56, 10 July 1998.

51 IRIN-WA, Weekly Roundup, 57, 17 July 1998. 
governmental organisations such as the CPLP might be held to enjoy benefits such as a shared language and heritage whilst remaining a step removed from the dynamics of regional politics. Indeed, the Economist Intelligence Unit (EIU) considered the main benefits of the CPLP mediation to be 'traditional linguistic, cultural and political ties between the [CPLP's] Contact Group and the warring parties' ${ }^{52}$ Following a meeting on the Portuguese warship Corte Real anchored off Bissau city, a Memorandum of Understanding was signed calling for 'formal negotiations to start within eight days, a de-militarised zone around the strategically located town of Mansoa, the deployment of peacekeeping troops from Portuguesespeaking countries and the opening of corridors of humanitarian aid ${ }^{53}$ To this end, Portuguese Defence Minister Jose Penedos offered to send troops to serve in the proposed peacekeeping force, but only under the auspices of a CPLP-led initiative. An appendix to the Memorandum foresaw the rival forces maintaining their relative positions at the start of the ceasefire. ${ }^{54}$ The most contentious issue, the withdrawal of Senegalese and Guinean forces was not explicitly mentioned. Hostilities never fully ceased. The evening after the signing of the truce, the Senegalese Defence Minister Samba Mané announced on television that the rebels had already broken the truce. For their part the Junta accused government troops of destroying a bridge outside Bafata. However, neither side rescinded the agreement. ${ }^{55}$

At this point the mediation process was dominated by the lusofonia. The Memorandum of Understanding foresaw long-term peace negotiations being conducted by the CPLP on board a Portuguese naval vessel. ECOWAS might participate but only on the same level and basis as other parties such as the UN, OAU and EU. ${ }^{56}$ Those representatives of the lusofonia involved in the mediation efforts were triumphant. A Portuguese daily newspaper claimed the CPLP 'reborn form the ashes' and ' affirmed as an organisation able to carry out an important role in the part of Africa which speaks Portuguese'. ${ }^{57}$

The CPLP's success in mediation, as well as the military position on the ground, caused ECOWAS to review its own strategy. On 4 August the ECOWAS Committee of Seven met in Accra. The meeting reaffirmed support for the Senegalese and Guinean intervention. However, the tenor of discourse towards the Junta and the CPLP was more conciliatory. After preliminary meetings between the

\footnotetext{
52 EIU, Country Report: Guinea-Bissau, 4th Quarter 1998, p.28.

53 IRIN-WA, Update, 259, 27 July 1998.

$54 \quad$ Marchés Tropicaux, 31 July 1998, p.1633.

$55 \quad$ Ibid., p.1633.

56 MacQueen, Norrie, 'A Community of Illusions? Portugal, the CPLP and Peacemaking

in Guiné-Bissau', International Peacekeeping, 10/2 (2003), p.14.

$57 \quad$ Diario de Noticias [Lisbon], 27 July 1998.
} 
Committee and the warring parties, and between ministers from the two communities, a joint ECOWAS/CPLP Consultative Meeting was held on 25 August at Praia under the joint chairmanship of the Ministers of Foreign Affairs of Côte d'Ivoire on behalf of ECOWAS and Cape Verde on behalf of the CPLP. As a result the truce of 25 July became a formal ceasefire. A Ceasefire Agreement was drafted providing for 'the reopening of the airport to allow in humanitarian assistance, an international observer force and a buffer zone along the border with Senegal'. ${ }^{58}$

A further round of inconclusive talks was held in Abidjan on 16 September. Proposals for a large-scale interposition force were stymied by the intransigence of the Senegalese and Guinean governments. Dakar envisaged a continuing military presence along the Casamance border, insisting that it would only withdraw its forces if requested by the Vieira government. The Junta flatly refused that demand. The meeting only managed agreement on the deployment of a small ECOWAS/CPLP observer force.

Although the ceasefire held, tension between the two parties remained high. After reaching Banjul en route to Bissau, the Junta negotiating team was stranded for three weeks as Senegal refused permission for them to overfly its territory. The delegation only reached Bissau after the French, Portuguese and Swedish Ambassadors agreed to fly them to Bissau city in a French helicopter under the auspices of the Red Cross. Meanwhile, Senegal had sought to justify its intervention on the international stage at the $53^{\text {rd }}$ Session of the UN General Assembly. Jacques Baudin, Senegal's Foreign Minister, reconfirmed Senegal's adherence to the dubious bilateral defence pacts with Guinea-Bissau. He added that Senegal's aim was to secure peace and end 'the threat to public security and to foreigners, and contribute to reinforcing stability and security in the sub-region and in Africa'. ${ }^{59}$ On 14 October fierce fighting resumed in Bafata, and then in Bissau and Gabu.

Within days Junta forces had taken Bafata and Gabu, inflicting serious casualties on loyalist troops, as well as the Senegalese and Guineans. Rebel forces fought to within 500 yards of the Presidential Palace in Bissau. As the fighting intensified the capital city emptied once more, with over 50,000 people fleeing to Safim, Nhacra, and Bissora to the north and Prabis to the west, as well as leaving in boats for the Bijagos Islands. Smaller numbers of refugees crossed into Guinea. The UN World Food Programme announced that renewed fighting would halt the ongoing delivery of rice to the scattered displaced persons from the initial exodus.

EIU, Country Report: Guinea-Bissau, 4th Quarter 1998, p.29. IRIN-WA, Weekly Roundup, 69, 9 October 1998. 
On 21 October Vieira declared a unilateral ceasefire. Two days later, with the whole country except central Bissau city in their hands, the Junta accepted a truce.

Once more Gambia led mediation efforts, albeit within the wider framework of the existing, flawed, ECOWAS conflict management structure. The Treaty of ECOWAS signed in Cotonou in July 1993, requires member states 'to employ where appropriate, good offices, conciliation, mediation and other methods of peaceful settlement of disputes', as well as establishing 'a regional peace and security observation system and peacekeeping forces where appropriate' ${ }^{60}$ Between 25 October and 30 October a series of meetings were held in Banjul between Vieira and Mané, during which, according to a senior Gambian official, there was much 'tough talking' by the hosts acting as mediators. ${ }^{61}$ The key obstacles remained Senegalese fears over the security of its southern border, and the Junta's determination that foreign troops leave Guinea-Bissau. With an agreement pending, the Gambian mediators arranged for the two sides to be flown to Abuja where a summit meeting of ECOWAS Foreign Ministers was being held. Henceforward, the CPLP would take a nominal role. Following the closure of the summit on 31 October, talks continued between the warring parties together with Presidents Jammeh of Gambia and Abdulsalam Abubakar of Nigeria, and Foreign Ministers from Ghana, Niger, Senegal and Togo.

On 1 November 1998, Vieira and Mané signed the 'Abuja Agreement'. A peace plan was framed. Senegalese and Guinean troops would be replaced by an ECOMOG force. The Agreement required the formation of a government of national unity to include members of the Junta to be followed in March 1999 by legislative and presidential elections to be monitored by ECOWAS, the CPLP and the international community. Shortly after the signing of the Agreement Foreign Ministers from the Committee of Nine went to New York to brief the UN Security Council on the proposed intervention. ${ }^{62}$ After commending the mediation efforts of ECOWAS and the CPLP, the Security Council authorised a limited Chapter VI peacekeeping intervention 'to facilitate the return to peace and security by monitoring the implementation of the Abuja Agreement'. ${ }^{63}$

\footnotetext{
60 Treaty of ECOWAS, Chapter X, Article 58, Para. 2, Sub-para e and f, Cotonou, 24 July 1993.

61 Interview with William Joof (Permanent Secretary to the Office of the President, Gambia), Banjul, 24 January 2000.

62 At the time the Security Council comprised several parties interested in the conflict. Aside from France as a permanent member, Portugal and Gambia had seats as nonpermanent members.

63 UN Security Council resolution 1216, S/RES/1216 (1998).
} 
Despite funding and logistical assistance from France the ECOMOG force was slow to deploy, undermanned and proved ineffective in fulfilling an overambitious mandate. However, the intervention was successful in its narrow aim of allowing a reasonably dignified exit for the battered troops from Senegal and Guinea. On 6 May 1999, despite the presence of the ECOMOG force, Mané chose to exercise his overwhelming military superiority. Vieira was swept from power into exile.

\section{Conclusion}

Zartman remarks that African states 'know how to make a deal, more than they know how to keep one'. ${ }^{64}$ The Guinea-Bissau civil war was replete with potential deals brokered by the gamut of would-be mediators. The response of the African continental and regional organisations tasked with conflict management was, however, disappointing. From the start of the conflict, and throughout its duration, mediation was often driven by the sort of ad hoc initiatives that have characterised conflict management in Africa since the independence era. The OAU proved unwilling and unable to mediate the conflict preferring to accept the ascendancy of Chapter VIII subsidiarity as the norm. Thus ECOWAS was promoted as the organisation of first resort. Yet, as had been the case in Liberia and Sierra Leone, the internal rivalries and divergent agendas within the regional organisation undermined the effectiveness of its mediation efforts. Moreover, on this occasion Nigeria was unwilling because of diplomatic overstretch and domestic preoccupations to take a leading role in the peace process. This emphasises the limitations of Nigeria as regional hegemon, whilst underlining ECOWAS reliance on Nigeria for effective conflict management. Without Nigeria the francophone bloc directed an ill-conceived, unrealistic and ineffective ECOWAS response to the conflict with active support from its extra-African sponsor, France. Indeed, the peace process was notable for the continued involvement of former colonial powers in sub-regional security dynamics. France used its influence within the francophone bloc of ECOWAS to further its support for the incumbent Vieira, whilst Portugal sought to counter French influence and re-establish its own position in GuineaBissau by resuscitating an essentially cultural entity - the CPLP. The effect of this external sponsorship was the creation of rival mediation efforts working at crosspurposes and with different objectives. The CPLP's efforts were eventually overtaken by ECOWAS mediation. This was partially a result of the latter's experience in conflict management, but mainly because of the support ECOWAS received from the UN and OAU as institution of first resort. However, as MacQueen notes, 'Portugal achieved as much as it could in its parallel but linked objectives:

64 Zartman, I. William, 'Diplomacy in Africa', Saisphere (2003), p.40. 
legitimising its intervention [in Guinea-Bissau] by framing it as a CPLP initiative while enhancing the standing of the CPLP itself' ${ }^{65}$ French involvement was less successful. Support for the initial Senegal/Guinea intervention and the ECOMOG operation came to nothing and the side Paris opposed - Mané's rebels - came to power. Whilst impartiality is not a pre-requisite for effective mediation the degree of bias shown by ECOWAS and the CPLP hindered the conflict resolution process in the case of Guinea-Bissau. However, it was the international governmental organisation rather than the regional organisation that succeeded in breaking the impasse and establishing a basis for negotiation. ECOWAS once more demonstrated that internal division and inherent institutional shortcomings in conflict management process are brakes on its ability to effectively mediate conflict. The disingenuous hardline stance against military takeovers adopted by ECOWAS led to the organisation supporting a highly unpopular leader in Vieira, whilst taking sides against the majority of the population. Until the latter stages of the conflict it chose not to mediate, but rather became an actor in the conflict and arguably the greatest obstacle to a peaceful solution. The CPLP's relative success as mediator brings into question the current orthodoxy promoting subsidiarity. The performance of ECOWAS when it was constrained to assume the role of mediator belied the OAU and UN's assumption that it should be the organisation of first resort for regional conflict management. In terms of a multi-party approach to conflict mediation, Crocker et al make the point that, "whereas more is not necessarily better, it is not necessarily worse'. ${ }^{66}$ Whilst this is true in other cases, in Africa and elsewhere, it is not borne out by the Guinea-Bissau example. A multiplicity of would-be mediators exacerbated and prolonged the conflict. In cases where the potential mediators are as at odds as the combatants the current application of the subsidiarity model fails. Prime responsibility for mediation should revert to the wider international community. In Africa's case - and depending on the individual circumstances of the conflict - this should be the AU or the UN.

\footnotetext{
65 MacQueen, op.cit., p.21.

66 Crocker et al, op.cit., p.511.
} 